\title{
21. Managing Gender: The 2010 federal election
}

\author{
Marian Sawer ${ }^{1}$
}

The 2010 federal election was the first in Australian history in which a woman prime minister was campaigning for the re-election of her government. Paradoxically, her party had no women's policy - or at least did not launch one publicly. Despite the avoidance of any policy focus on gender issues, gender was a significant undercurrent in the election, as reflected in consistent gender gaps in public opinion and voting intentions. Unusually, the management of gender turned out to be more of a problem for a male than for a female leader.

\section{Gender Gaps and Gendered Coverage}

Gender was expected to feature prominently in the 2010 campaign given the contest between Julia Gillard as Australia's first woman prime minister and Tony Abbott, a hyper-masculine Opposition leader and ironman triathlete. Abbott's persona was that of an 'action man' always ready to don lycra and a helmet for some strenuous sporting activity; the Coalition campaign slogan was 'Real action'. Abbott was also known for telling women how to live their lives, criticising them for taking 'the easy way out' by having abortions and blocking the importation of abortion drug RU486 while he was Health Minister. While the Abbott action-man persona might have been useful in a contest with Kevin Rudd, who was to be framed as 'all talk and no action', it was less useful in a contest with Julia Gillard. It required various forms of softening, particularly through referencing of the women in his life, but also through less-aggressive presentation and promises not to tinker with access to abortion. Despite these attempts to remake his image, Abbott was largely unsuccessful in presenting himself as a new man, at least in the eyes of women voters.

Fewer women than men approved of Tony Abbott and indeed Newspoll showed the gender gap increasing during the campaign (see Table 21.1). More women than men approved of Julia Gillard, but the gender gap was smaller (Newspoll and The Australian 2010). Nielsen also showed gender gaps in approval of

\footnotetext{
1 An earlier version of this chapter appeared in the Australian Review of Public Affairs (October 2010, $<$ www.australianreview.net $>$ ). Marian Sawer also wishes to thank John Stirton of Nielsen and Gillian Evans and Kirsty McLaren for assistance with public opinion data, Janet Wilson for parliamentary data and Pam Debenham for permission to reproduce her 'It's about time' T-shirt.
} 
Abbott and Gillard, with Abbott having the wider gap. ${ }^{2}$ The gendered nature of the reactions to the leaders was also highlighted by Roy Morgan's 'polligraph', used on Channel Seven for the leaders' debate on 25 July. The polligraph (pink and blue worms charting audience responses) showed women reacting more favourably to Gillard than men and less favourably to Abbott, except when Abbott was talking about his paid parental-leave package.

Table 21.1 Gender Gap on 'Who Would Make the Better Prime Minister?'

\begin{tabular}{|l|l|c|c|}
\hline & Date & $\begin{array}{c}\text { Male } \\
\text { (\%) }\end{array}$ & $\begin{array}{c}\text { Female } \\
\text { (\%) }\end{array}$ \\
\hline \multirow{3}{*}{ Julia Gillard } & 23-25 July \& 30 July - 1 August 2010 & 49 & 52 \\
\cline { 2 - 4 } & 30 July - 1 August \& 6-8 August 2010 & 47 & 52 \\
\hline \multirow{2}{*}{ Tony Abbott } & 23-25 July \& 30 July - 1 August 2010 & 38 & 31 \\
\cline { 2 - 4 } & 30 July - 1 August \& 6-8 August 2010 & 39 & 30 \\
\hline
\end{tabular}

Sources: Newspoll and The Australian.

In general, qualities associated with leadership such as strength, authority and decisiveness are regarded as male traits, while double standards are often applied to women displaying such traits (as illustrated by the 'Attila the Hen' description of British Prime Minister Margaret Thatcher). Women leaders generally have to work harder to manage their gender. If they are consultative and consensus seeking, they will be regarded as feminine and not tough enough for leadership. If they mimic what is regarded as a masculine leadership style, they may be put down as 'Attila the Hen' or, in any event, regarded as strident and overly ambitious (Kellerman and Rhode 2007, 7). The fact that there was a larger gender gap in approval of Abbott than of Gillard suggests that, unusually, it was the male leader who had the greater problem in managing gender. His portrayal of invincibility and invulnerability did not work in his favour, at least among women, while Gillard's leadership style was more likely to appeal to both men and women, even if particularly to women.

2 For example, Nielsen, 'Estimates of federal voting intention and leadership approval: three poll weighted average', 20-22 July 2010, 27-29 July 2010, 3-5 August 2010 (courtesy John Stirton, Nielsen). In contrast with the commercial polling organisations, the Australian Election Study found a larger gender gap in approval of Gillard than of Abbott. 
The leaders' debate - at the end of a week in which Gillard was riding high in the polls - was promptly followed by what looked like an attempt to counter her advantage. Veteran political journalist Laurie Oakes was the recipient of yet another leak - this one to the effect that Gillard had opposed paid parental leave and the rise in old-age pensions when they came up in Cabinet. Both of these issues were of disproportionate importance to women, who might well be looking to women in government to champion them. Gillard's response to the leak - that she was simply being 'financially responsible' when querying the cost of paid parental leave and the old-age pension increase - was in tune with much of her campaign. Her focus on financial competence or 'managing the economy' accorded with the policy priorities usually identified with male rather than female voters, who generally place more emphasis on health and education (that is, on social expenditure rather than cuts to it). ${ }^{3}$

Given the continuing gender gap in voting intentions (Figures 21.1 and 21.2) Labor focused its attention on male voters. Hence the Prime Minister appeared wherever possible in a hard hat rather than playing to her advantage among women. The 'modern gender gap', with women to the left of men in voting behaviour, has appeared both in North America and in Europe (Inglehart and Norris 2000) and has been evident in New Zealand since 1996. The Australian Election Study (AES) has similarly shown fewer women than men voting for the Coalition since 2001 and a particularly big gap between university-educated men and women (Bean and McAllister 2009, 209; Wilson and Hermes 2009, 18). The 2010 AES data suggested that women were 9 percentage points less likely to have voted for the Coalition than men, and 8 points more likely than men to have voted for Labor (see Bean and McAllister in this volume). In other words, the modern gender gap had well and truly arrived in Australia; if women had voted the same way as men, the Coalition would have had an easy victory.

3 For example, Roy Morgan poll, 14 August 2010. 


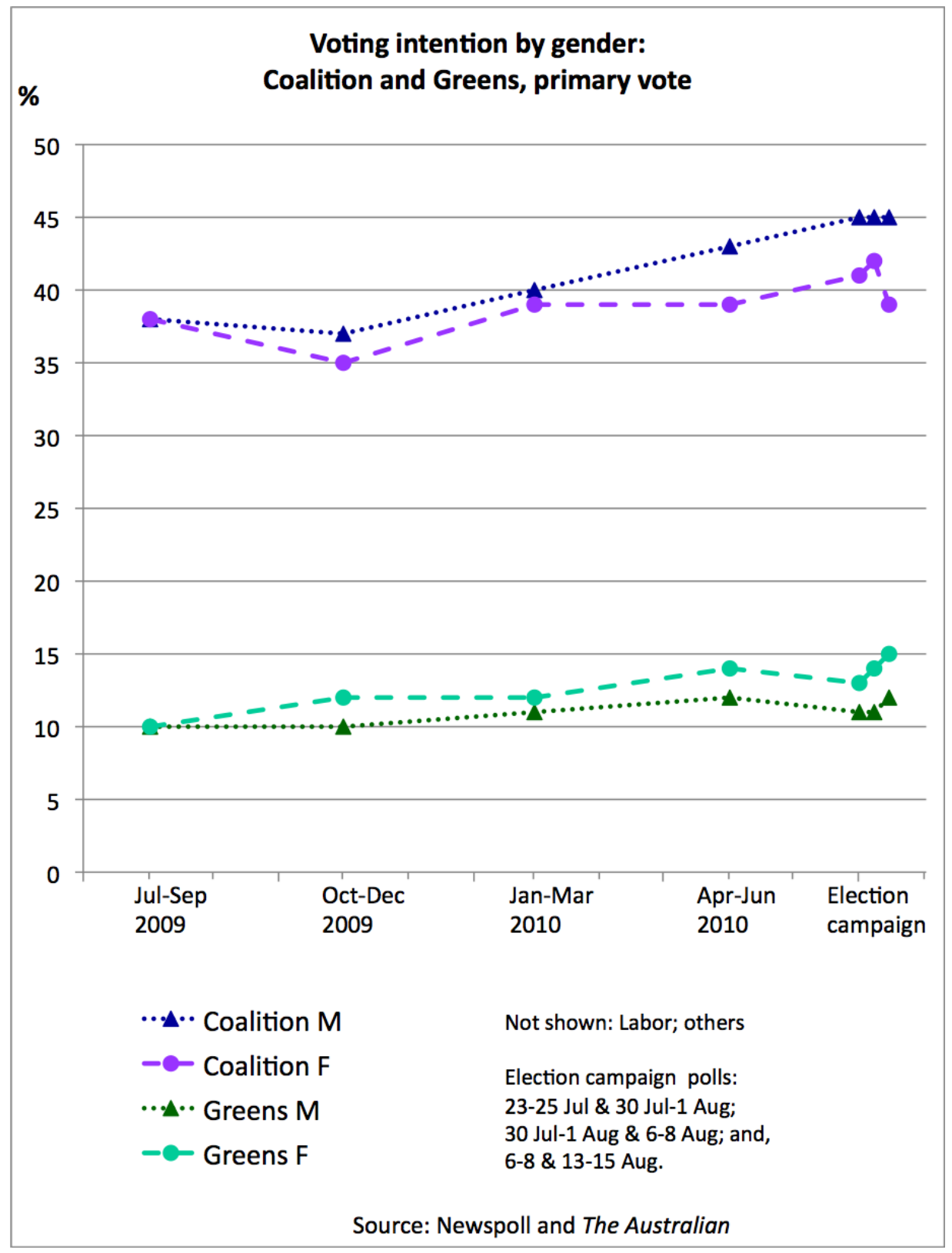

Figure 21.1 Voting Intention by Gender: Coalition and Greens, primary vote (per cent)

Source: Newspoll and The Australian. 


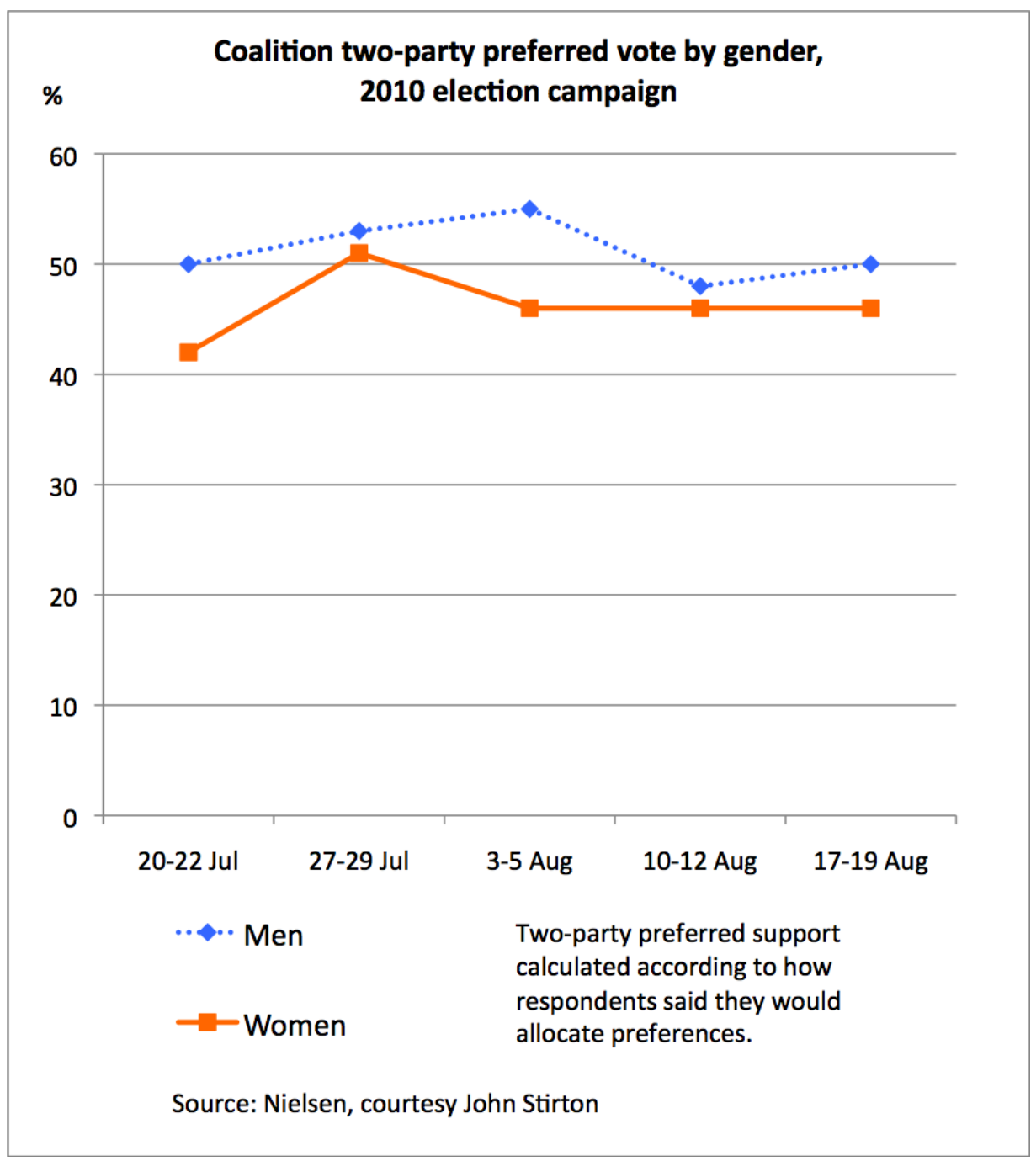

Figure 21.2 Coalition Two-Party Preferred Vote by Gender, 2010 Election Campaign

Source: Nielsen, courtesy John Stirton. 
Despite the understandable preoccupation with male voters on the part of Labor strategists, others were more concerned at the possible effects of the Cabinet leak on women's votes and the boost it might provide to Abbott's campaign. In Victoria, 45 prominent women signed a letter to The Age (published on 10 August 2010) warning that Abbott's views and past policies would undermine the respect and equality women had fought to achieve and that there was good reason to fear that he would again try to impose his religious beliefs. Various incidents during the campaign seemed to confirm such fears, such as Abbott's inappropriate use of the anti-rape campaign slogan 'No means no' to attack Julia Gillard. When the media seized upon his repeated referencing of the slogan, Abbott accused Labor of a smear campaign to discredit him with women voters (Leslie 2010).

Gillard herself studiously avoided gender issues, including this one. She did benefit from the glamorous cover stories provided by Women's Weekly, Women's Day and New Idea and from the enthusiasm among many women, in particular, that a woman had at last reached the top job (see Figure 21.3). Such 'gender affinity' effects have been noted elsewhere, with parties experiencing a boost among women voters when they are led by women (Banducci and Karp 2000). EMILY's List, the fundraising and support mechanism for 'progressive' Labor women candidates, did attempt to persuade the Labor Party to capitalise on enthusiasm for a first woman prime minister by running a gender-based campaign. Its own gender-based polling in marginal seats suggested that women would respond to such a campaign and were wary of Abbott imposing his moral views. When it became clear that the party would not undertake such a campaign, EMILY's List undertook its own, designing and distributing womencentred election material including distribution of 20000 'Why women can't trust Tony' leaflets in marginal electorates. It also engaged in online campaigning through Facebook and Twitter (Kovac 2010). Nonetheless, it pointed out in its submission to the party's post-election review that its campaigning work would have been much easier if the party had itself undertaken a high-profile launch of gender-based initiatives and ideas (see 'Campaign policies' below).

Despite her personal avoidance of gender themes, was Gillard singled out for gendered criticism? The following examples suggest that, as in the 2007 election, in 2010, sexist news coverage did little damage and was, if anything, counterproductive. It might also be - as found by a recent study of media coverage of Hillary Clinton's campaign for the White House (Lawrence and Rose 2010) - that the more aggressive forms of sexist bias have migrated to the Internet and are now to be found on blogs and other forms of social media. 


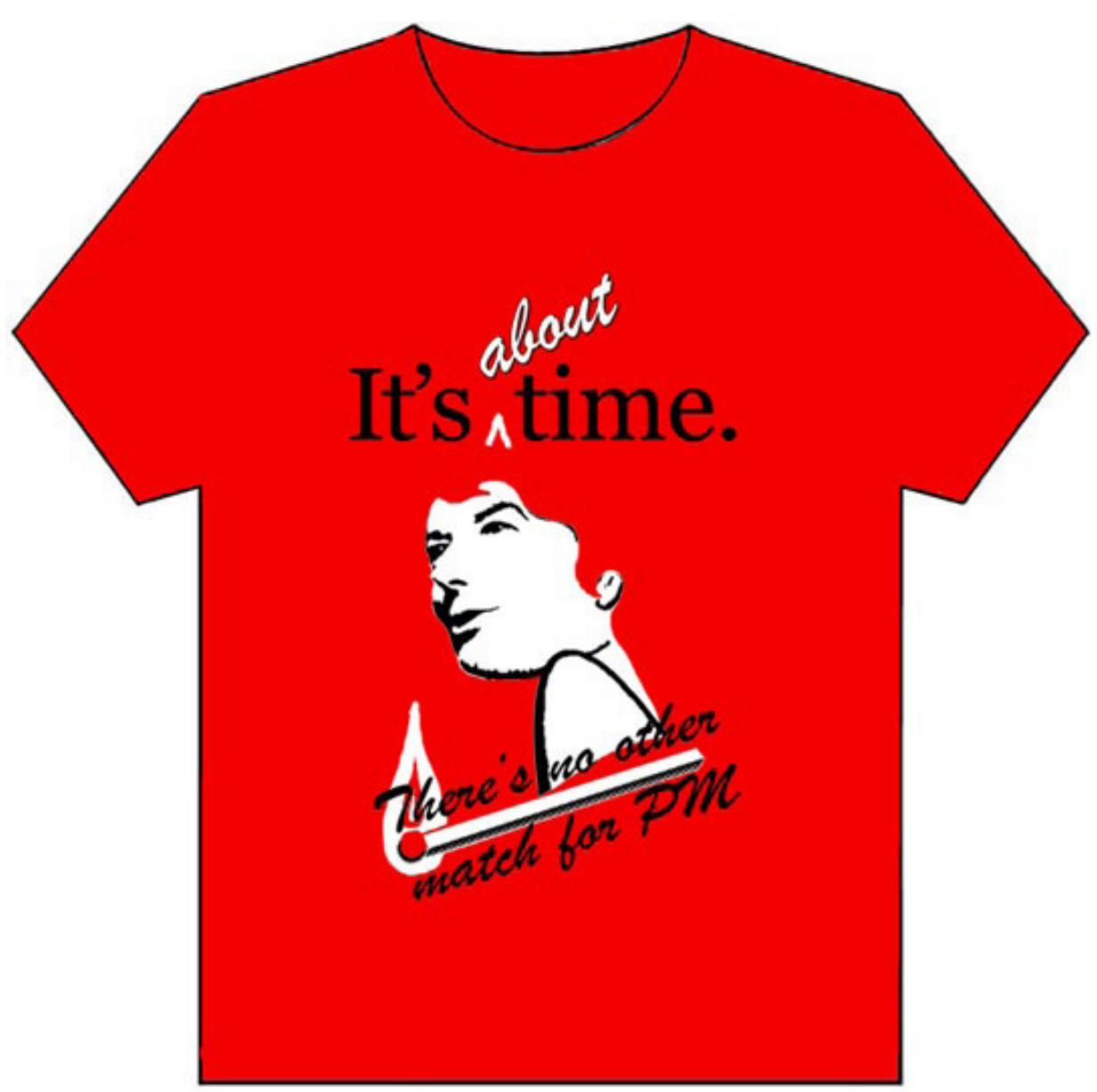

Figure 21.3 Pam Debenham's 'It's about time' T-shirt

Source: Pam Debenham, Canberra artist.

Nonetheless, Gillard's private life was subjected to an extraordinary level of scrutiny, with even her 'de facto's' traffic offences becoming a front-page story in The DailyTelegraph (30 July 2010). Tony Abbott's references to knowing what it was like to bring up a family (for example, his first words in the leaders' debate) and his use of his eldest daughter, Louise, in the campaign were part of 'playing the family card'. Liberal Party research had suggested that family was a potent issue and campaign strategists were keen that Abbott's family be seen everywhere and often (Savva 2010, 307). The sight of Abbott's family was to serve as a reminder to voters that Gillard was unmarried and childless and hence supposedly out of touch on work/life issues. In 2007, Coalition Senator Bill Heffernan had suggested that Gillard was unsuitable to lead the nation because she was 'deliberately barren' (Sawer 2009,171). 
Some went further, for the benefit of those who might forget that Gillard was not only out of touch with Australian families but also living in sin. While religious leaders largely abstained when asked to comment on Gillard's 'de facto' status, Jim Wallace of the Australian Christian Lobby was quick to say both that it would be 'a factor in the way that many Christians vote' and that Christians would be hoping 'her own arrangements' did not preclude Ms Gillard from empathising with traditional families wrestling with 'issues integral to raising children' (Morris 2010). The leader of the Family First Senate ticket in Queensland proclaimed that a prime minister in a de facto relationship was 'not a good role model' (The Courier-Mail, 10 August 2010).

The emphasis on Abbott's family credentials and Gillard's supposed lack of them is strongly reminiscent of the television advertisement used by the New Zealand National Party in 1999, which introduced its leader as 'mother of Ben and Anna, a wife and the New Zealand Prime Minister'. The intent was to remind the electorate that the Labour leader, Helen Clark, was not a mother and hence could not understand traditional family values or the issues involved in raising a family (Dore 1999). Clark differed from Gillard in that she did marry her partner before entering Parliament-under pressure from senior Labour Party officials. Gillard not only did not marry, she did not cook. Her lack of interest in the kitchen was not, however, interpreted as contempt for the values of 'homemakers', as happened to Hillary Clinton in 1992. Indeed attacks on Gillard's personal life if anything rebounded, as indicating a lack of respect for women's choices.

\section{Campaign Policies}

Despite the advent of Australia's first woman prime minister, neither the Coalition nor Labor appeared to have produced a women's policy for the 2010 election or any overall plan for achieving gender equality. This was in a context where the gender pay gap was widening, where there had been a major childcare crisis and where the participation of women in public decision making was going backwards relative to other democracies. In one of the best-kept secrets of the campaign, however, Labor did actually produce a policy-called Equality for Women - and released it the day before the election, without a launch or telling anybody. It was not included in the list of policies on the ALP web site, but could be located if you knew the name of the policy.

Relating to the portfolio, Labor launched two policies on specific matters. At a 'Women, Management and Work' conference in Sydney, on 29 July, Minister for the Status of Women, Tanya Plibersek, announced a policy to increase the number of women on boards through scholarships in the private sector and a 40 
per cent target for Federal Government boards. Then on 9 August, she launched in Melbourne 'Federal Labor's National Plan to Reduce Violence against Women and their Children', a plan resulting from two years of consultation and evidence collection. There was a funding commitment of $\$ 44.5$ million over four years, maintaining spending at a level similar to previous years (for example, \$50.3 million for the Partnerships against Domestic Violence Strategy 1997-2005, followed by \$75.7 million for the Women's Safety Agenda 2005-09).

The lack of focus on women's policy was highlighted when the Prime Minister 'forgot' to allocate the Status of Women portfolio when releasing the details of her new ministry on 11 September. By the time the ministry was sworn in by the Governor-General, Quentin Bryce, Status of Women had been added to the Employment Participation and Childcare portfolio of Kate Ellis. There was some comment on Ellis's lack of previous involvement with gender equity issues and her backing by the powerful right-wing trade union, the Shop, Distributive and Allied Employees Association (SDA) - noted for its anti-abortion stance (Vasek 2010). On the other side of politics, the previous Coalition Status of Women spokeswoman, Sharman Stone, lost her frontbench position and the portfolio was given to Shadow Parliamentary Secretary Senator Michaelia Cash, from the right of the party.

Over the years the status of Status of Women has slipped in Australia: originally the portfolio was located in the Prime Minister's Department and carried by the Prime Minister, with the help of a Minister Assisting the Prime Minister (also usually of Cabinet rank). In 2004, the portfolio was demoted to a line department but the Prime Minister continued to have nominal responsibility for it, assisted by a Cabinet minister. Under the Rudd and Gillard governments, the Prime Minister has no longer claimed the portfolio, which has been left with a junior minister (Tanya Plibersek and then Kate Ellis from September 2010).

The Equality Rights Alliance (ERA), based in the YWCA, represents more than 50 women's advocacy organisations and is one of the six women's alliances funded by the Rudd Government since 2010 to support policy engagement by women at the national level. Its mode of operation is similar to preceding women's peak bodies, with its policy work open to endorsement (or otherwise) by its member organisations but not requiring unanimity. For the election, it undertook the kind of rating of party policies previously the domain of the Women's Electoral Lobby (WEL), which still conducted its own rating exercise, assessing policies against responsiveness to feminist values.

The ERA ratings were arrived at by assessment of funding and other commitments made by the parties against policy priorities agreed by member organisations. There were some methodological difficulties caused by the late release by parties of funding commitments or the inability to provide them, and it seems 
likely that ERA will switch to the WEL methodology for the next election. ${ }^{4}$ On the ERA ratings matrix, the Greens did best and the Coalition worst, with the Coalition failing to make any commitment to stronger sex discrimination laws or the improvement of government data collection, meaning data disaggregated by gender, age, location and disability to enable better responses to particular needs. ${ }^{5}$

The Coalition's paid parental-leave proposal was more generous than Labor's, at least for women earning more than the minimum wage, and included superannuation payments as well as being for a longer period (six months rather than 18 weeks). Nonetheless, there was distrust among women's advocacy organisations of the sudden policy turn-around by the Coalition on the issue. There was also criticism of the Coalition's proposal that the leave payments be made through the welfare system rather than by employers, on the grounds it would be seen as a form of welfare rather than an employment entitlement.

Labor fuelled this distrust through repeated reference to Abbott's earlier statement that paid parental leave would only happen 'over this Government's dead body' ( $A M, 22$ July 2002, ABC Radio). It should be noted that in 2003 Abbot was also responsible for the abolition of the Work and Family unit in his Department of Employment and Workplace Relations, accepting the position of the Australian Chamber of Commerce and Industry that such matters should be the subject of negotiation between employers and employees rather than of government policy.

Interestingly, one of the most progressive elements of the Coalition policy - and one highlighted by the shadow minister in her second reading speech on the government's Paid Parental Leave Bill — was barely mentioned by Tony Abbott. Sharman Stone stressed that the Coalition would follow Sweden, Iceland and Norway in introducing a 'use it or lose it' paternity leave component, to encourage fathers to bond with their newborn babies and to share and diminish what would otherwise be the 'mother-only experience of an interrupted career' (Stone 2010). During the election campaign, Labor appropriated the Coalition's 'use it or lose it' component and committed to introducing it by July 2012.

The Coalition did not produce a women's policy for the election but did have a page on its web site entitled 'Advancing Women', which offered women a 'direct say' in Coalition policies: 'We know time is precious for all women... So we are making it as easy as possible to be involved. Send us your views directly by email.' The content or effect of this 'direct say' was not at all clear. Abbott's conversion to paid parental leave, for example, was repeatedly said to

4 Interview with Kathy Richards, Manager, Equality Rights Alliance, 21 September 2010.

5 It is interesting that for the NSW State election of 2011 the Coalition did make a commitment to the establishment of a Bureau of Women's Statistics within the (NSW) Office for Women's Policy. 
have come about because he listened to his wife and children ('some of us have them', as Liberal frontbencher Bronwyn Bishop interjected in one of her maleidentifying moments in Parliament; Bishop 2010).

The top item in the ERA's election priorities was 'closing the gender wage gap'. A poll commissioned by the Diversity Council of Australia during the campaign found that 76 per cent of Australians supported steps being taken to close the gap between men's and women's earnings (Auspoll 2010). Gender gap research commissioned by EMILY's List in June also suggested that pay equity was an important issue in its targeted marginal seats (EMILY's List Australia 2010). This priority was signally absent from the campaign debate despite at least three immediate issues being on the table. First, the Government response to recommendations of the House of Representatives inquiry into pay equity (Making it Fair, 2009) was still overdue. Second, government commitment to funding any increase in wages for community-sector workers resulting from the Australian Services Union equal pay test case was still unclear. Third, it was still not known whether the Government was going to address the widening gender pay gap in the Australian Public Service caused by agency-level rather than centralised wage fixing. ${ }^{6}$

The secretive Labor Party women's policy did in fact include the commitment 'to work through the funding implications of any increase in wages awarded as a result of the Australian Services Union's national pay equity case' (ALP 2010). After the election, there was a row over the Commonwealth submission to the case, which seemed to renege on prior commitments in the interests of returning the budget to surplus (Australian Government 2010, 10). After threatened strike action, the Commonwealth 'clarified' its position as not requiring that financial considerations take precedence over pay equity. Meanwhile, the Coalition made no commitment at all on the subject.

\section{Contenders}

The Greens continued to field the most women candidates while the gap between the ALP and the Coalition widened slightly due to the continued decrease in women Coalition candidates (Table 21.2). After the election, the number of Coalition men in the House of Representatives rose by eight, but the number of Coalition women remained constant at fourteen. Overall, the number of women in the House of Representatives fell to 24.7 per cent, with a significant gap

6 After the election the Special Minister of State announced that any reform of wage-fixing arrangements would be put off for another three years, despite the large gaps that had opened up between salaries paid to those at the same level, depending on whether they were employed in male-dominated or female-dominated departments and agencies. 
between Labor and the Coalition (Figure 21.4). To use a term from international comparative studies, there has been 'stagnation' in women's representation in the House of Representatives over the past four elections; women's representation has been stuck at the 25 per cent level, with 2 per cent or less variation.

Table 21.2 Gender Breakdown of 2010 House of Representatives Nominations, Selected Parties

\begin{tabular}{|l|c|c|c|}
\hline Party & Male & Female & Female (\%) \\
\hline Greens & 88 & 62 & 41.3 \\
\hline ALP & 103 & 47 & 31.3 \\
\hline Family First & 76 & 32 & 29.6 \\
\hline Independents & 65 & 17 & 20.7 \\
\hline LNP & 24 & 6 & 20.0 \\
\hline Liberals/CLP & 88 & 23 & 19.8 \\
\hline Nationals & 15 & 1 & 6.2 \\
\hline
\end{tabular}

Source: Australian Electoral Commission.

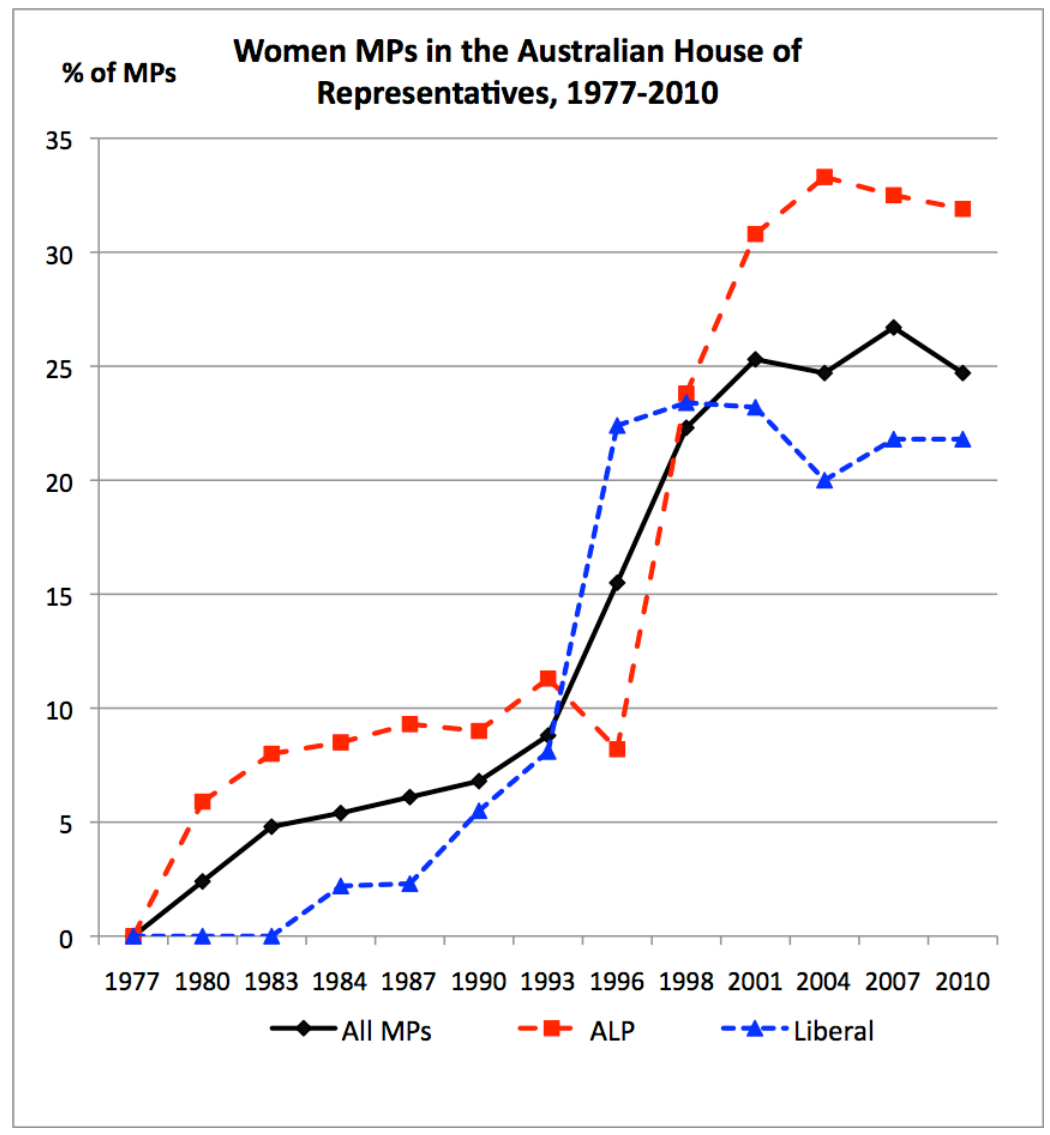

Figure 21.4 Women MPs in the Australian House of Representatives, 1977- 
The number of women in the Senate, however, rose to the record level of 39.5 per cent (as of 2011), thanks largely to three new women senators for the Greens, although The Nationals also had a second woman senator (Tables 21.3 and 21.4).

Table 21.3 Gender Breakdown of the House of Representatives after the 2010 Election

\begin{tabular}{|l|c|c|c|}
\hline Party & Male & Female & Female (\%) \\
\hline ALP & 49 & 23 & 31.9 \\
\hline Liberals/LNP/CLP* & 47 & 14 & 21.8 \\
\hline Nationals/LNP & 11 & 0 & 0.0 \\
\hline Independents & 5 & 0 & 0.0 \\
\hline Greens & 1 & 0 & 0.0 \\
\hline Total & 113 & 37 & 24.7 \\
\hline
\end{tabular}

* MPs allocated in accordance with their party room (Crook allocated to Independents, Griggs to Liberals) Source: Parliamentary Library.

Table 21.4 Gender Breakdown of the Senate, 1 July 2011

\begin{tabular}{|l|c|c|c|}
\hline Party & Male & Female & Female (\%) \\
\hline Greens & 3 & 6 & 66.7 \\
\hline ALP & 17 & 14 & 45.2 \\
\hline Nationals/CLP* & 4 & 2 & 33.3 \\
\hline Liberals & 20 & 8 & 28.6 \\
\hline Other & 2 & 0 & 0.0 \\
\hline Total & 46 & 30 & 39.5 \\
\hline
\end{tabular}

* Senator Scullion sits in The Nationals' party room

Source: Parliamentary Library.

One of the problems with allowing the number of women in Parliament to slip is the reduction in the pool of women available for entry into ministerial positions. Although the drop in the House of Representatives was partially compensated for in the Senate - from whence women ministers have been disproportionately drawn - the tradition of the Senate supplying only about one-third of ministers puts limits on this source. Australia already has a smaller proportion of women in its national Cabinet (20 per cent in the current Gillard Cabinet) than any comparable democracy apart from the new Cameron Government in the United Kingdom (17 per cent).

In some countries such as Finland and Spain, women are a majority of Cabinet members, while they are about half in Norway and Sweden, 37 per cent in Germany and one-third in France and New Zealand. Indeed the 2008 change of government in New Zealand illustrates how such proportions have become the 
norm under both social democratic and conservative governments. Interestingly, women tend to be 'over-represented' in Cabinets in other countries (relative to their presence in Parliament), as they were 20 years ago in Australia (Moon and Fountain 1997, 458). In Australia the opposite is now true. For example, women are 36 per cent of the Federal Parliamentary Labor Party but only 20 per cent of Cabinet (Table 21.5). One economical explanation is that while quotas apply to Labor parliamentary preselections they do not apply to ministerial selection.

While it was a difficult time for the most likely new candidate for Cabinet responsibility (Tanya Plibersek was expecting a baby in October), the general outcome was disappointing, with the number of women in Cabinet remaining the same and falling by one in the ministry as a whole (from seven to six). On the other hand, the allocation of the finance portfolio to Senator Penny Wong was the first time that a woman had held an economic portfolio in a federal Labor government. ${ }^{7}$

Table 21.5 Gender Breakdown of the Gillard Ministry and the Opposition Shadow Ministry, September 2010

\begin{tabular}{|l|c|c|c|}
\hline Ministry category & Male & Female & Female (\%) \\
\hline Cabinet & 16 & 4 & 20.0 \\
\hline Whole ministry & 24 & 6 & 20.0 \\
\hline Parliamentary secretaries & 6 & 6 & 50.0 \\
\hline Shadow Cabinet & 18 & 2 & 10.0 \\
\hline Shadow ministry & 26 & 6 & 18.8 \\
\hline Shadow parliamentary secretaries & 11 & 3 & 21.4 \\
\hline
\end{tabular}

\section{Conclusion}

It was paradoxical that while Australia had at last joined other democracies in having women in the positions of both head of government and head of state, Australia was slipping down the Inter-Parliamentary Union's (IPU) ranking of countries on representation of women in the National Parliament. Australia dropped from fifteenth place in 1999 to thirty-fourth place before the 2010 election and to fortieth place after the election (IPU, 30 September 2010). And this was at a time when there were a large number of gender issues requiring the attention of both the Government and the Parliament-most notably, the widening gender gap in wages and the urgency of funding equal pay for community-service workers. Australia was prioritising gender equity in its international development assistance to perhaps an unprecedented degree, but closer to home these issues were struggling to gain attention.

7 Senator Margaret Guilfoyle had become the first woman Finance Minister at the federal level 30 years before, in the Coalition Government of Malcolm Fraser. 


\section{References}

Auspoll. 2010. 'Australian attitudes to pay equity'. Auspoll, 6 August.

Australian Labor Party (ALP). 2010. Equality for Women, 20 August. Canberra: Australian Labor Party. <http://www.alp.org.au/agenda/more---policies/ equality-for-women>

Australian Government. 2010. Australian Government Submission to the Equal Remuneration Case, 18 November. Melbourne: Fair Work Australia.

Banducci, Susan A. and Karp, Jeffrey A. 2000. 'Gender, Leadership and Choice in Multiparty Systems'. Political Research Quarterly 53(4): 815-848.

Bean, Clive and McAllister, Ian. 2009. 'The Australian election survey: the tale of the rabbit-less hat. Voting behaviour in 2007'. Australian Cultural History 27(2): 205-218.

Bishop, Bronwyn. 2010. Interjection, Second Reading Speech by Maxine McKew on the Paid Parental Leave Bill 2010. House of Representatives Debates, 27 May, 4405.

Dore, Christopher. 1999. 'Mother of a challenge'. The Australian, 26 November.

EMILY's List Australia. 2010. Gender Gap Research 2010-Recommendations for campaigning and policy. Melbourne: EMILY's List.

Inglehart, Ronald and Norris, Pippa. 2000. 'The developmental theory of the gender gap: women's and men's voting behaviour in global perspective'. International Political Science Review 21(4): 441-463.

Kellerman, Barbara and Rhode, Deborah L. (eds). 2007. Women and Leadership: The state of play and strategies for change. San Francisco: Jossey-Bass.

Kovac, Tanja. 2010. Winning elections for Labor women - a constant campaign. Discussion Paper for EMILY's List submission to Federal Election Review 2010.

Lawrence, Regina G. and Rose, Melody. 2010. Hillary Clinton's Race for the White House: Gender politics and the media on the campaign trail. Boulder: Lynne Rienner.

Leslie, Tim. 2010. 'Abbott defends "no means no" remark'. ABC News, 3 August.

Moon, Jeremy and Fountain, Imogen. 1997. 'Keeping the gates? Women as ministers in Australia, 1970-96'. Australian Journal of Political Science 32(3): 455-466. 
Morris, Linda. 2010. 'On PM's personal values, religious leaders keep respectful distance'. Sydney Morning Herald, 28 July.

Newspoll and The Australian. 2010. 'Who would make the better prime minister?'. Newspoll and The Australian, July-August.

Savva, Nikki. 2010. So Greek: Confessions of a conservative leftie [Second edn]. Melbourne: Scribe.

Sawer, Marian. 2009. 'Women and the 2007 federal election'. Australian Cultural History 27(2): 167-174.

Stone, Sharman. 2010. Second Reading Speech on the Paid Parental Leave Bill 2010, House of Representatives Debates, 27 May: 4383-4384.

Vasek, Lanai. 2010. “Question mark" over Ellis'. The Australian, 15 September.

Wilson, Shaun and Hermes, Kerstin. 2009. Shifting Majorities: Examining class, birthplace and gender in the victories of Howard and Rudd. Paper presented to Australian Political Studies Association Conference, Macquarie University, Sydney, <http://www.pol.mq.edu.au/apsa/papers/Non-refereed \%20papers/> 